\title{
HUBUNGAN ANTARA PENGETAHUAN KADER POSYANDU TENTANG KANKER PAYUDARA DENGAN SADARI
}

\author{
Relationship Between Knowledge Of The Integrated Services Post Cadre About \\ Breast Cancer With Self Breast Examination (BSE) \\ Sab'ngatun ${ }^{1)}$ Lilik Hanifah ${ }^{2)}$ \\ STIKES Mamba'ul ‘Ulum Surakarta \\ sabngatun@yahoo.com
}

\begin{abstract}
ABSTRAK
Latar Belakang : Penyakit kanker merupakan salah satu penyebab kematian utama di seluruh dunia. Penyebab terbesar kematian akibat kanker setiap tahunnya salah satunya kanker payudara. 43\% dari seluruh kasus kanker dapat dicegah, salah satu upaya pencegahan kanker payudara dengan SADARI. Penelitian ini bertujuan untuk mengetahui hubungan antara pengetahuan kader posyandu tentang kanker payudara dengan SADARI.

Metode : Penelitian ini merupakan penelitian survei analitik dengan pendekatan crossectional. Populasi dalam penelitian ini seluruh kader posyandu di Kalurahan Mojosongo Jebres Surakarta sebanyak 60 responden. Teknik pengambilan sampel dengan accidental sampling, sampel dalam penelitian ini adalah kader posyandu yang datang dan ditemui pada saat pertemuan kader sebanyak 30 responden. Alat pengumpulan data berupa kuisioner, analisis data dengan chi square.

Hasil : Pengetahuan kader tentang kanker payudara mayoritas pada kategori cukup 11 responden (50\%). Mayoritas melakukan SADARI sebanyak 24 responden $(80 \%)$. Hasil uji statistic menunjukkan hasil 0,006<0,05 dapat diartikan bahwa Ho ditolak dan Ha diterima, yaitu ada hubungan yang signifikan antara pengetahuan kader posyandu tentang kanker payudara dengan SADARI.

Simpulan : ada hubungan yang signifikan antara pengetahuan kader posyandu tentang kanker payudara dengan SADARI
\end{abstract}

Kata Kunci: Pengetahuan, Kanker Payudara, SADARI

\begin{abstract}
Background: Cancer is one of the leading causes of death worldwide. The biggest cause of cancer deaths every year is breast cancer. $43 \%$ of all cancer cases can be prevented, one of the efforts to prevent breast cancer with BSE. This study aims to determine the relationship between integrated services post cadre's knowledge about breast cancer and BSE.

Method: This study is an analytical surveillance study with a crossectional approach. The population in this study were all 60 integrated services post cadres in Mojosongo Jebres Surakarta. Sampling techniques with accidental sampling, the sample in this study were integrated services post cadres who came and were
\end{abstract}


met at the time of the cadre meeting as many as 30 respondents. Data collection tools in the form of questionnaires, data analysis with chi square.

Results: Majority of knowledge about breast cancer in the majority of respondents was 11 respondents (50\%). The majority of doing BSE were 24 respondents (80\%). The results of the statistical test show the results of 0.006 $<0.05$ can be interpreted that Ho is rejected and Ha is accepted, ie there is a significant relationship between the knowledge of integrated services post cadre's integrated services post cadres about breast cancer and BSE.

Conclusion: there is a significant relationship between knowledge of integrated services post cadres about breast cancer and BSE

Keywords: Knowledge, Breast Cancer, BSE

\section{PENDAHULUAN}

Penyakit kanker merupakan salah satu penyebab kematian utama di seluruh dunia. Pada tahun 2012, kanker menjadi penyebab kematian sekitar 8,2 juta orang. Berdasarkan data GLOBOCAN International Agency for Research on Cancer (IARC) diketahui bahwa pada tahun 2012 terdapat 14.067.894 kasus baru kanker dan 8.201.575 kematian akibat kanker di seluruh dunia. Penyebab terbesar kematian akibat kanker setiap tahunnya antara lain disebabkan kanker paru, hati, perut, korektal dan kanker payudara. (Pusdatin, 2016)

Organisasi Penanggulangan Kanker Dunia dan Badan Kesehatan Dunia, memperkirakan terjadi peningkatan kejadian kanker di dunia 300 persen pada tahun 2030, dan mayoritas terjadi di negara-negara berkembang termasuk Indonesia. (Pusdatin, 2016)

Pada tahun 2017 ini diprediksikan hampir 9 juta orang meninggal di seluruh dunia akibat kanker dan akan terus meningkat hingga 13 juta orang per tahun di 2030. Di Indonesia, prevalensi penyakit kanker juga cukup tinggi. Menurut data Riskesdas 2013, prevalensi kanker di Indonesia adalah 1,4 per 100 penduduk atau sekitar 347.000 orang. (Kemenkes, 2017)

Berdasarkan estimasi jumlah penderita kanker, Jawa Tengah merupakan provinsi dengan estimasi penderita kanker terbanyak, yaitu sekitar 68.638 orang diikuti Jawa Timur dengan estimasi penderita kanker sebanyak 61.230 orang. Kanker tertinggi yang terjadi pada perempuan di Indonesia adalah kanker payudara dan kanker serviks. (Pusdatin, 2016)

Kasus kanker payudara di Jawa Tengah terjadi peningkatannya cukup signifikan. Pada 2015 ada 654 penderita, meningkat lagi menjadi 749 penderita, dan meningkat menjadi 1.373 penderita di 2017. Penyebabnya salah satunya faktor lingkungan yakni terkait pola makan yang tidak beraturan, semakin tingginya polusi udara, campuran bahan-bahan lain dalam pengolahan tanaman sayur, hingga kadar logam berat di perairan. (Tribun Jateng, 2018)

Kanker payudara cenderung berdampak pada perempuan yang memasuki usia senja diatas 50 tahun. Terdapat 8-10 kasus kanker payudara terjadi di usia tersebut. Selain disebabkan oleh faktor genetik dan lingkungan, kebiasaan gaya 
hidup sehari-hari. Ancaman kanker payudara meningkat seiring dengan perubahan pola hidup masyarakat. (Depkes, 2016)

Prevalensi kanker terbesar adalah kanker serviks dan payudara yang diderita oleh kaum perempuan dengan prevalensi kanker serviks sebesar 0,8 per seribu penduduk dan kanker payudara sebesar 0,5 perseribu penduduk. Provinsi Jawa tengah menempati urutan ke enam secara nasional, tetapi prevalensinya diatas rata-rata nasional yaitu 1,2 per seribu penduduk, sementara kanker payudara 0,7 per seribu penduduk. Lebih dari 30\% kematian akibat kanker disebabkan oleh lima faktor risiko perilaku dan pola makan, yaitu: (1) Indeks massa tubuh tinggi, (2) Kurang konsumsi buah dan sayur, (3) Kurang aktivitas fisik, (4) Penggunaan rokok, dan (5) Konsumsi alkohol berlebihan. (Nevi, 2015)

Penyebab kanker payudara belum diketahui secara pasti. Wanita-wanita yang infertil (yang tidak memiliki anak) memiliki kemungkinan yang lebih besar untuk terkena kanker payudara. Penyakit ini juga memiliki kecenderungan bersifat familiar, artinya seorang wanita dengan ibu penderita kanker payudara, memiliki kemungkinan lebih besar untuk terserang kanker ini. Wanita yang mendapatkan menstruasi pertama pada usia yang sangat awal (kurang dari 12 tahun) atau wanita yang terlambat mengalami menopause (di atas 50 tahun) memiliki kemungkinan yang lebih besar terkena kanker ini. Begitu pula dengan para wanita yang menderita penyakit kista pada payudaranya, wanita yang telah menderita kanker pada payudara yang satunya, atau wanita yang memiliki banyak papiloma (tonjolan tonjolan kecil) pada payudaranya (Olfah, 2013).

Menurut Kementrian Kesehatan (2017) sebenarnya 43\% dari seluruh kasus kanker dapat dicegah, sedangkan 30\% lainnya dapat disembuhkan bila ditemukan dan diobati pada keadaan dini.

Pemerintah memiliki sejumlah kebijakan dan program pengendalian kanker di Indonesia yang bertujuan untuk meningkatkan deteksi dini, penemuan dan tindak lanjut dini kanker; meningkatkan kualitas hidup penderita kanker; dan menurunkan angka kematian akibat kanker. Untuk mencapai tujuan tersebut, dilaksanakan program pengendalian kanker yang meliputi upaya promotif dan preventif dengan meningkatkan pengetahuan masyarakat akan kanker, pengadaan kegiatan pemberdayaan masyarakat berupa Posbindu PTM / Pos Pembinaan Terpadu Penyakit Tidak Menular, dan juga deteksi dini kanker. (Kemenkes, 2017)

Upaya pencegahan primer kanker adalah dengan melakukan pembiasaan gaya atau perilaku hidup sehat yang dikenal dan disingkat dengan cerdik. Cek kesehatan secara rutin, rajin aktivitas dan olahraga, diet seimbang, istirahat cukup dan kelola stres. Sedangkan upaya deteksi dini kanker, lakukan kegiatan deteksi dini dengan singkatanwaspada yaitu waktu buang air besar atau kecil ada perubahan atau gangguan. Alat pencernaan terganggu dan susah menelan, suara serah dan batuk yang tidak sembuh sembuh, payudara atau tempat lain ada benjolan atau tumor, andeng-andeng yang berubah sifatnya menjadi besar dan gatah, darah atau lendir yang keluar dari tubuh, adanya koreng atau borok yang tidak mau sembuh sembuh. (Nevi, 2015)

Program deteksi dini kanker payudara dengan edukasi periksa payudara sendiri (SADARI) dan Pemeriksaan Payudara Klinis (SADANIS). Sadari dan sadanis ini diperuntukkan pada wanita usia 30-50 tahun. Cakupan deteksi dini 
SADANIS di tahun 2016 meningkat menjadi 1.925 .943 orang $(5,1 \%)$ dibandingkan dengan cakupan tahun 2015 yang berjumlah 1.268 .333 orang (3.4\%) (Kemenkes, 2017).

Penelitian yang dilakukan oleh Kusumasari (2009) yang meneliti tentang ada tidaknya hubungan antara pengetahuan kanker payudara dan perilaku SADARI pada wanita, berdasarkan hasil analisis data diperoleh koefisien korelasi (r) sebesar 0,256 dengan taraf signifikasi sebesar 0,011 $(\mathrm{p}<0,05)$ sehingga hasil analisis menunjukkan ada hubungan yang positif antara pengetahuan tentang kanker payudara dengan perilaku SADARI. Hal tersebut berdasarkan model keyakinan kesehatan, yaitu ketika individu memiliki pengetahuan yang baik akan kanker payudara maka ia akan mengambil tindakan menjaga kesehatan dengan melakukan deteksi dini kanker payudara yakni SADARI.

Berdasarkan latar belakang di atas makan penulis tertarik mengambil judul "Hubungan Antara Pengetahuan Kader Posyandu Tentang Kanker Payudara Dengan SADARI.”

\section{METODE PENELITIAN}

Penelitian ini merupakan penelitian survey analitik dengan pendekatan crossectional. Variabel independeni dalam penelitian ini adalah pengetahuan kader posyandu tentang kanker payudara, sedangkan variabel depende adalah SADARI. Populasi dalam penelitian ini adalah semua kader posyandu di Kalurahan Mojosongo sebanyak 60 responden, pengambilan sampel dengan teknik accidental sampling pada saat pertemuan kader, sampel dalam penelitian ini sebanyak 30 responden. Alat pengumpulan data berupa kuisioner dan analisis data menggunakan chi square.

\section{HASIL DAN PEMBAHASAN}

Tabel 1. Distribusi Frekuensi Relatif Karakteristik Responden Menurut Umur, Pendidikan, Pekerjaan, Dan Paritas

\begin{tabular}{clcc}
\hline No & \multicolumn{1}{c}{ Umur } & Jumlah & Prosentase $(\%)$ \\
\hline 1. & 26-35 Tahun & 3 & 10 \\
2. & 36-45 Tahun & 5 & 17 \\
3. & 46-55 Tahun & 16 & 53 \\
4. & 56-65 & 6 & 20 \\
\multicolumn{2}{c}{ Jumlah } & 30 & 100 \\
\hline No & \multicolumn{1}{c}{ Pendidikan } & Jumlah & $\%$ \\
\hline 1 & SD & 2 & 7 \\
2 & SMP & 5 & 17 \\
3 & SMA & 15 & 50 \\
4 & PT & 8 & 26 \\
\multicolumn{2}{r}{ Jumlah } & 30 & 100 \\
\hline
\end{tabular}




\begin{tabular}{clcc}
\hline No & Paritas & Jumlah & $\%$ \\
\hline 1 & Nulipara & 1 & 3 \\
2 & Primi para & 2 & 7 \\
3 & Multipara & 27 & 90 \\
& Jumlah & 30 & 100 \\
\hline No & Pekerjaan & Jumlah & $\%$ \\
\hline 1 & IRT & 23 & 77 \\
2 & Swasta & 3 & 10 \\
3 & Wiraswasta & 3 & 10 \\
4 & PNS & 1 & 3 \\
& Jumlah & 30 & 100 \\
\hline
\end{tabular}

Berdasarkan tabel 1. karakteristik responden sebagian besar berumur 4655 tahun yaitu sebanyak 16 responden (53\%), pendidikan mayoritas SMAsebanyak 15 responden (50\%), paritas mayoritas multipara sebanyak 27 responden (90\%) dan pekerjaan mayoritas IRT sebanyak 23 responden $(77 \%)$.

Tabel 2. Distribusi Frekuensi Relatif Tingkat Pengetahuan Kader Posyandu Tentang Kanker Payudara

\begin{tabular}{clcc}
\hline \multirow{2}{*}{ No } & Pengetahuan & Jumlah & Persentase (\%) \\
\hline 1. & Baik & 11 & 37 \\
2. & Cukup & 15 & 50 \\
3. & Kurang & 4 & 13 \\
& Jumlah & 30 & $100 \%$ \\
\hline
\end{tabular}

Dari tabel 2 diketahui bahwa mayoritas pengetahuan responden pada kategori cukup sebanyak 15 responden (50\%)

Tabel 3. Distribusi Frekuensi Relatif SADARI

\begin{tabular}{cccc}
\hline No & Upaya Melakukan SADARI & Jumlah & Persentase (\%) \\
\hline 1. & Melakukan & 24 & 80 \\
2. & Tidak melakukan & 6 & 20 \\
& Jumlah & 30 & 100 \\
\hline
\end{tabular}

Tabel 3 Menunjukkan mayoritas responden melakukan SADARI sebanyak 24 responden $(80 \%)$

Tabel 4. Crostab pengetahuan kader posyandu tentang kanker payudara dengan SADARI

\begin{tabular}{ccccc}
\hline \multirow{2}{*}{ Pengetahuan } & \multicolumn{3}{c}{ SADARI } & \multirow{2}{*}{$\begin{array}{c}\text { Chi Square } \\
p\end{array}$} \\
\cline { 2 - 3 } & \multicolumn{2}{c}{ Tidak melakukan } & Melakukan & \\
\hline Kurang & $3(10 \%)$ & $1(3,3 \%)$ & $4(13,3 \%)$ \\
Cukup & $3(10 \%)$ & $12(40 \%)$ & $15(50 \%)$ & \\
Baik & $0(0 \%)$ & $11(36,7 \%)$ & $11(36,7 \%)$ & 0,06 \\
Jumlah & $6(20 \%)$ & $24(80 \%)$ & $30(100 \%)$ & \\
\hline
\end{tabular}


Berdasarkan tabel 4 diketahui bahwa mayoritas responden berpengetahuan baik dan mayoritas melakukan SADARI sebanyak 11 responden $(36,7 \%)$

Berdasarkan hasil uji Chi square yang diolah dengan komputerisasi sistem SPSS (Statistical Product and Service Solution) for Windows Release 17.0 dengan taraf kesalahan $5 \%$ dengan hasil 0,006 sehingga 0,006<0,05 dapat diartikan bahwa Ho ditolak dan Ha diterima, yaitu ada hubungan yang signifikan antara pengetahuan kader posyandu tentang kanker payudara dengan SADARI.

Berdasarkan tabel 1. Berdasarkan tabel 1. karakteristik responden sebagian besar berumur 46-55 tahun, berpendidikan SMA, paritas multipara dan pekerjaan mayoritas IRT. Responden merupakan kader posyandu dimana kader adalah warga masyarakat setempat yang dipilih dan ditinjau oleh masyarakat dan dapat bekerja secara sukarela mengelola posyandu.

Tabel 2. Menunjukkan pengetahuan responden pada kategori cukup. Menurut Notoatmodjo dalam Wawan (2011) pengetahuan adalah hasil dari tahu dan ini terjadi setelah seseorang mengadakan penginderaan terhadap suatu objek tertentu. Pengetahuan dipengaruhi oleh pendidikan, umur, pekerjaan, budaya, pengalaman dan lingkungan. Semakin cukup umur, tingkat kematangan dan kekuatan seseorang akan lebih matang dalam berfikir dan bekerja. Dari segi kepercayaan masyarakat seseorang lebih dewasa lebih dipercaya daripada yang belum tinggi kedewasaannya. Semakin tinggi status ekonomi, pendidikan juga semakin tinggi, sehingga pengetahuan juga semakin tinggi. (Wawan, 2011)

Dari hasil penelitian bisa dilihat bahwa mayoritas responden berpendidikan D3 dan S1 memiliki pengetahuan baik, dan responden yang berpengetahuan kurang berpendidikan SD dan SMP. Responden berpengetahuan cukup mayoritas berpendidikan SMA. Jadi dapat disimpulkan bahwa semakin tinggi pendidikan seseorang maka akan semakin baik pula pengetahuan.

Berdasarkan hasil penelitian mayoritas responden berpengetahuan cukup, responden berstatus sebagai ibu rumah tangga, ibu rumah tangga mempunyai banyak waktu luang untuk mengakses informasi, serta banyak waktu luang untuk berkontribusi di posyandu, sehingga responden sebagai ibu rumah tangga aktif pada kegiatan pertemuan kader, dimana pada kegiatan pertemuan kader akan mendapatkan banyak informasi tentang kesehatan.

Responden dengan pengetahuan cukup juga mayoritas pada kelompok umur 30-50 tahun, semakin tinggi usia, maka tingkat kematangan seseorang akan semakin baik sehingga pengetahuan juga semakin baik, tetapi semakin lanjut usia akan mengalami penurunan daya ingat. Hasil penelitian Abdullah (2013) sebanyak 57,8\% memiliki pengetahuan baik, hal ini dikarenakan mahasiswa semester IV telah mendapatkan materi tentang kanker payudara. Sehingga faktor yang mempengaruhi pengetahuan dalam penelitian ini adalah pendidikan formal, semakin tinggi pendidikan, maka semakin baik pengetahuan). Penelitian sejalan juga dilakukan oleh Angraini (2017) mayoritas pengetahuan responden tentang kanker payudara pada kategori kurang sebanyak 62\%, hal ini dipengaruhi oleh minat responden untuk mengakses informasi kurang serta kurangnya kewaspadaaan terhadap kanker payudara.

Berdasarkan tabel 3. mayoritas responden melakukan SADARI. Dalam penelitian ini banyak responden yang sudah melakukan SADARI dikarenakan 
responden seorang kader posyandu sebagai tangan panjang petugas kesehatan dalam memberikan penyuluhan kepada masyarakat tentang SADARI dengan demikian responden sangat mengerti akan pentingnya deteksi dini kanker payudara dengan SADARI sehingga responden hafal akan gerakan SADARI dan melaksanakan SADARI setiap bulan.

Pada penelitian yang dilakukan oleh Nugrahini (2012) perilaku responden dalam melakukan SADARI memiliki perilaku sesuai sebesar $56,25 \%$, responden yang tidak sesuai perilaku SADARI dikarenakan mahasiswa yang telah mempelajari SADARI dalam sistem reproduksi tetapi belum dilaksanakan. Pengetahuan yang ditunjang pada perilaku yang sesuai sangat penting, dalam hal ini perilaku mahasiswa yang sesuai dalam melakukan SADARI penting untuk pemeriksaan dini pada dirinya sendiri.

Penelitian Wulandari (2017) responden menunjukkan perilaku tidak melakukan SADARI dapat disebabkan karena kurangnya stimulus yang memotivasi responden untuk melakukan SADARI. Kurangnya stimulus melakukan sadari yang diterima responden menyebabkan responden kurang termotivasi untuk melakukan sadari. Semakin rendah stimulus yang diterima seseorang maka perilaku yang ditunjukkan semakin negatif. Stimulus yang diberikan kepada organisme adpat diterima atau ditolak, apabila stimulus tersebut ditolak berarti stimulus tersebut tidak efektif dalam mempengaruhi perhatian individu dan apabila stimulus tersebut diterima oleh individu berarti stimulus tersebutefektif. (Wawan, 2011). Hal ini meskipun stimulusnya sama bagi beberapa responden dalam melakukan SADARI, namun respon responden berbeda-beda.

Pada penelitian Aufi (2010) mayoritas responden tidak melakukan SADARI yaitu 26 responden atau 86,66\%. Dari wawancara didapatkan faktor lain yang mempengaruhi responden tidak melakukan SADARI karena responden belum tahu cara melakukan SADARI dan manfaat dari SADARI. Menurut Wawan (2011) faktor yang mempengaruhi perilaku seseorang bukan hanya dari pengetahuan saja. Budaya atau kebiasaan sehari-hari dalam masyarakat, agama, serta informasi yang cukup turut berpengaruh dalam membentuk sikap dan perilaku sesorang,

Berdasarkan tabel 4. Bahwa responden dengan pengetahuan baik akan melakukan sadari, dan berdasarkan hasil uji chi square dengan taraf signifikansi 95\% diperoleh hasil $\mathrm{p}=0,006<\mathrm{p}(0,05)$ disini berarti $0,006<0,05$ sehingga Ho ditolak yang artinya ada hubungan antara pengetahuan kader posyandu tentang kanker payudara dengan SADARI.

Perilaku yang didasari oleh pengetahuan akan lebih lama bertahan daripada perilaku yang tidak didasari pengetahuan dan kesadaran, maka tidak akan berlangsung lama (Wawan, 2011)

Dalam penelitian ini responden dengan pengetahuan kurang mayoritas tidak melakukan sadari, responden dengan pengetahuan cukup mayoritas melakukan sadari dan responden berpengetahuan baik semua melakukan sadari. Dalam hal ini dapt diketahui bahwa faktor pembentuk perilaku salah satunya dipengaruhi oleh pengetahuan, semakin baik pengetahuan maka semakin baik pula perilakukan, dalam penelitian ini semaikn baik pengetahuan responden tentang 
kanker payudara dan deteksi dini dengan sadari maka responden akan melakukan sadari. Menurut Wawan (2011) tingkat pengetahuan berpengaruh terhadap perilaku seseorang dimana orang akan berperilaku sesuai dengan pengetahuan yang dimilikinya atau diperolehnya.

Upaya melakukan SADARI merupakan perilaku kesehatan yang dipengaruhi oleh pengetahuan yang dimiliknya. Sadari juga merupakan upaya seseorang dalam mempertahankan dan meningkatkan kesehatannya, karena sadari merupakan sarana deteksi dini kanker payudara. Menurut Notoatmodjo (2009) perilaku kesehatan (Health Behavior), yaitu hal-hal yang berkaitan dengan tindakan atau kegiatan seseorang dalam memelihara dan meningkatkan kesehatannya. Termasuk juga tindakan-tindakan untuk mencegah penyakit, kebersihan perorangan, memilih makanan, sanitasi dan sebagainya.

Menurut teori Lawrence Green (1980) dalam Purwoastuti (2015) faktor perilaku dibentuk oleh faktor predisposisi yaitu pengetahuan, sikap, kepercayaan, keyakinan, nilai dan sebagainya, faktor pendukung yang terwujud dalam lingkungan fisik, tersedia atau tidak tersedianya fasilitas atau sarana kesehatan, faktor pendorong yang terwujud dalam sikap dan perilaku petugas kesehatan dan perilaku masyarakat.

Hasil penelitian ini sejalan dengan penelitian Angraini (2017) dimana hasil uji statistik $p$ value diperoleh $0,007<0,05$ artinya Ho ditolak, hal ini menggambarkan ada hubungan pengetahuan dengan pelaksanaan SADARI di SMK N 1 Teluk Kuantan tahun 2016. Menurut asumsi peneliti terdapatnya hubungan yang signifikan antara pengetahuan tentang SADARI dalam mendeteksi dini kanker payudara kemungkinan berkaitan dengan kurangnya minat responden untuk mencari informasi tentang kanker payudara dan cara pemeriksaan SADARI serta kurangnya kewaspadaan terhadap kanker payudara.

Hasil penelitian ini berbeda dengan penelitian Abdullah (2013) hasil uji statistik diperoleh nilai $\mathrm{p}=0.96>0,05$ berarti tidak ada hubungan antara pengetahuan tentang kanker payudara dengan cara sadari pada mahasiswa semester IV program Studi Ilmu Keperawatan FK UNSRAT Tahun 2013.

\section{SIMPULAN DAN SARAN}

\section{Simpulan}

Pengetahuan kader tentang kanker payudara mayoritas pada kategori cukup 11 responden (50\%). Mayoritas melakukan SADARI sebanyak 24 responden $(80 \%)$. Hasil uji statistic menunjukkan hasil 0,006<0,05 dapat diartikan bahwa Ho ditolak dan Ha diterima, yaitu ada hubungan yang signifikan antara pengetahuan kader posyandu tentang kanker payudara dengan SADARI.

\section{Saran}

Responden sebagai kader kesehatan diharapkan dapat meningkatkan pengetahuan tentang kanker payudara dan selalu melakukan deteksi dini kanker payudara dengan SADARI minimal sebulan sekali. Dan Peneliti selanjutnya diharapkan dapat melakukan penelitian tentang deteksi dini kelainan payudara dengan sadari 


\section{DAFTAR PUSTAKA}

Abdullah Nurhayati, dkk. Hubungan Pengetahuan tentang kanker payudara dengan cara periksa payudara sendiri pada mahasiswa semester IV program studi ilmu keperawatan fakultas kedokteran universitas sam ratulangi. Ejornal keperawatan (e-Kp) Volume 1. Nomor 1. Agustus 2013 https://media.neliti.com/media/publications/105875-ID-hubunganpengetahuan-tentang-kanker-payu.pdf https://ejournal.unsrat.ac.id/index.php/jkp/article/viewFile/2223/1780

Angraini, Rizka 2017. Hubungan Pengetahuan, Sikap tentang Sadari Dalam mendeteksi Dini Kanker Payudara. Journal Endurance 2(2) June 2017 https://www.researchgate.net/publication/318399988_HUBUNGAN_PENGE TAHUAN_SIKAP_TENTANG_SADARI_DALAM_MENDETEKSI_DINI KANKER_PAYUDARA_PADA_REMAJA

Aufi Farkhah, 2012. Hubungan Tingkat Pengetahuan Wus Tentang Kanker Payudara Dengan Upaya Melakukan Sadari Di Desa Kacangan Rt 03 Rw 01 Kecamatan Andong Boyolali. Tahun 2010. Prodi DIII Kebidanan STIKES Mamba'ul 'Ulum Surakarta

Depkes, 2016. Bulan Peduli Kanker Payudara. http://www.depkes.go.id/resources/download/pusdatin/infodatin/InfoDatin\%2 0Bulan\%20Peduli\%20Kanker\%20Payudara_2016.pdf

Kemenkes, 2017. Kementerian Kesehatan Ajak Masyarakat Cegah Dan Kendalikan Kanker.

http://www.depkes.go.id/article/print/17020200002/kementerian-kesehatanajak-masyarakat-cegah-dan-kendalikan-kanker.html

Koesumasari, Ni Putu Okky Marth. 2009. Hubungan Antara Pengetahuan Kanker Payudara Dan Perilaku Sadari (Pemeriksaan Payudara Sendiri) Pada Wanita Dewasa Ini. SKRIPSI. Yogyakarta : Fakultas Psikologi Universitas Sanata Dharma https://repository.usd.ac.id/28461/2/039114091_Full\%5B1\%5D.pdf

Nevi Arfian, 2015. Cerdik \& Waspada Kunci Cegah Kanker, Kita Bisa Aku Bisa https://dinkesjatengprov.go.id/v2015/index.php/component/content/article/39rokcontent/frontpage/363-kanker

Notoatmodho, S. 2009. Promosi Kesehatan dan Perilaku Kesehatan. Jakarta: PT Rineka Cipta

Nugrahini, Dewi S, dkk. 2012. Hubungan Pengetahuan dengan Perilaku SADARI Pada Mahasiswa fakultas Ilmu Keperawatan Universitas Padjajaran. Students e-Journal Vol 1 No 1 (2012)

http://journal.unpad.ac.id/ejournal/article/view/729

Olfah, Y., dkk. 2013. Kanker Payudara \& SADARI. Yogyakarta : Nuha Medika

Pusdatin, 2016. Bulan Peduli Kanker http://www.pusdatin.kemkes.go.id/article/view/17020100002/bulan-pedulikanker-payudara.html diakses tanggal 9 Januari 2019 pukul 09.30 WIB

Purwoastuti, Endang dan Walyani, E.S. 2015. Perilaku \& Softskills Kesehatan (Panduan Untuk Tenaga Kesehatan). Yogyakarta : Pustakabarupress 
Tribun Jateng, 2018. Waspada Kanker Payudara http://jateng.tribunnews.com/2018/01/27/waspada-grafik-peningkatanpenderita-kanker-payudara-di-semarang-mencengangkan-ini-sebabnya

Wawan A \& Dewi. (2011) Teori dan Pengukuran Pengetahuan, Sikap Dan Perilaku Manusia. Yogyakarta : Nuha Medika

Wulandari, P dan Ayu, S.M. 2017. Hubungan Tingakt pengetahuan dan Sikap dengan Perilaku Pemeriksaan Payudara Sendiri (SADARI) Mahasiswa. http://eprints.uad.ac.id/5412/1/19.\%20HUBUNGAN\%20TINGKAT\%20PEN GETAHUAN\%20DAN\%20SIKAP\%20DENGAN\%20PERILAKU\%20PEM ERIKSAAN\%20PAYUDARA\%20SENDIRI\%20\%28SADARI\%29\%20MA HASISWI.pdf 